\title{
Pengaruh Model Mentoring Robert Clinton Terhadap Kecakapan Kepemimpinan Pekerja di GKII Daerah Pontianak
}

\section{Effects of Robert Clinton's Mentoring Model on Worker Leadership Skills in GKII of the Pontianak Region}

\author{
Herwinesastra $^{\mathrm{l})^{*}}$ \\ 1) Prodi Teologi Sekolah Tinggi Teologi Pontianak, Kalimantan Barat \\ ${ }^{*}$ Penulis korespondensi: herwine_sastra@yahoo.com
}

Received: 28 April 2019/Revised: 24 September 2019 /Accepted: 11 October 2019

\begin{abstract}
Abstrak
Penulis memfokuskan penelitian model mentoring terhadap pengembangan kecakapan kepemimpinan pekerja secara khusus pekerja di Gereja Kemah Injil Indonesia (GKII) Daerah Pontianak. Di samping itu juga penelitian ini diharapkan dapat memberikan teori-teori baru tentang model mentoring untuk pengembangan kecakapan kepemimpinan pekerja dan bahan acuan bagi para pemimpin gereja dalam mengembangkan pemimpin baru untuk meningkatkan pelayanan di Gereja Kemah Injil Indonesia (GKII) Daerah Pontianak. Penelitian ini merupakan penelitian kuantitatif dengan menggunakan analisis regresi berganda, analisis korelasi, dan koefisien determinasi. Hasil penelitian menunjukkan adanya korelasi dua variabel, yaitu variabel model mentoring Robert Clinton dan pengembangan kecakapan kepemimpinan yang sangat signifikan.
\end{abstract}

Kata-kata Kunci: mentoring, kecakapan, kepemimpinan, pekerja, gereja

The author focuses the research on the mentoring model on developing workers' leadership skills, specifically for workers in GKII in the Pontianak site. Besides, this research is also expected to be able to provide new theories about the mentoring model for the development of workers' leadership skills and reference materials for church leaders in developing new leaders to improve service in GKII in Pontianak. This research is a quantitative study using multiple regression analysis, correlation analysis, and the coefficient of determination. The results showed a correlation between two variables, namely Robert Clinton's mentoring model variable and the development of essential leadership skills.

Keywords: mentoring, skill, leadership, worker, church 


\section{Pendahuluan}

Mentoring adalah suatu konsep tentang seseorang diberi contoh oleh pembimbing yang lebih tua dan berpengalaman yang membantu anak didik yang lebih muda di sepanjang perjalanan. Yosua memiliki Musa sebagai mentornya. Elisa memiliki Elia sebagai mentornya. Timotius memiliki Paulus sebagai mentornya. Metode mentoring menjadi penting dalam mengembangkan sebuah kepemimpinan agar mampu menghadapi dan menjawab tantangan demi terciptanya keberhasilan bersama. Dalam bukunya, Leader Mentoring: Find, Inspire, and Cultivate Great Leaders, Michael Skenkman menegaskan bahwa jika tidak ada mentoring, tidak ada pemimpin. ${ }^{1}$ Salah satu faktor strategis dalam sebuah organisasi adalah mengembangkan orang-orang yang dipimpin melalui sebuah metode mentoring. Penelitian terdahulu oleh Madlock dan Kennedy-Lightsey, menyatakan mentoring memberikan pengaruh terhadap pengembangan karir dengan memberikan arahan secara profesional dan dukungan psikologi kepadan karyawan. ${ }^{2}$

Kepemimpinan merupakan topik yang hangat akhir-akhir ini untuk diteliti. Kepemimpinan yang efektif secara umum diakui masih kurang sebagai akibat kurangnya pengembangan pemimpin-pemimpin baru. Dalam menghadapi perubahan setiap organisasi tentunya membutuhkan sumber daya manusia yang berkualitas dalam rangka mendukung keberhasilan bagi sebuah organisasi. Pemimpin dan kepemimpinan menjadi faktor penentu keberhasilan sebuah organisasi dalam mencapai tujuannya. Pada sisi lain, pemimpin dan kepemimpinan juga dapat menjadi pemicu gagalnya organisasi memenuhi visi dan misinya. Muir menyebutkan bahwa para ahli setuju pengembangan kepemimpinan itu tidak dapat terjadi tanpa dukungan. Dukungan mutlak diperlukan karena itulah yang menolong pemimpin bertumbuh dalam kepemimpinannya. ${ }^{3}$

Pengembangan mentoring dalam sebuah kepemimpinan merupakan sebuah proses pembimbingan dengan kualitas tinggi, di mana fokus utamanya adalah bagaimana menghasilkan sumber daya

${ }^{1}$ Herdy N. Hutabarat, Mentoring dan Pemuridan (Bandung: Kalam Hidup, 2011), 49. Herdy N. Hutabarat mengutip pernyataan Michael Skenman, Leader Mentoring: Find, Inspire, and Cultivate Great Leaders.

2 Sofyati Sjofjan \& Aryanan Satrya, "Analisis Pengaruh Mentoring, Sikap Verbal Agresif Atas terhadap Kepuasan Komunikasi dan Komitmen Organisasional Karyawan Pada Perusahaan," (Jakarta: Fakultas Ekonomi Universitas Indonesia, 2013), 2-3, diakses 25 Februari 2018, http://lib.ui.ac.id/naskahringkas/2016-03/S46328-

Sofyati\%20Sjofjan.

${ }^{3}$ Douglas Muir, "Mentoring and Leader Identity Development: A Case Study," Human Resource Development Quarterly 25, no. 3 (September 2014): 354, https://doi.org/10.1002/hrdq.21194. 
manusia yang mampu dalam memahami kekuatan dan kelemahannya; menentukan posisi yang tepat dalam profesinya; dan memberikan pengalaman nyata dalam penerapannya. ${ }^{4}$ Setiap orang yang ada dalam lingkungan sebuah organisasi memiliki potensi dan peluang untuk berkembang. Pengembangan kepemimpinan sangat diperlukan guna menghadapi masa depan dalam sebuah organisasi. Abbas dan Sara, dalam penelitiannya menyatakan bahwa, kombinasi dari lima faktor dari pengembangan kepemimpinan memengaruhi kinerja sampai 50\%. ${ }^{5}$

Menurut survei tentang potensi manusia, diperkirakan bahwa rata-rata hanya 10 sampai $15 \%$ dari seluruh potensi maksimum manusia yang sempat digunakan seumur hidupnya. ${ }^{6}$ Dengan demikian, potensi manusia yang belum dimaksimalkan ada sekitar delapan puluh lima sampai sembilan puluh persen. Ada potensi yang tersimpan di dalam diri seseorang yang dapat dikembangkan oleh organisasi bahkan oleh seorang mentor dalam sebuah proses kepemimpinan.

Berdasarkan wawancara langsung penulis dengan Ketua Daerah Gereja Kemah Injil Daerah Pontianak periode 2016-2021, Pendeta Edi Kusnadi menyampaikan bahwa selama ini dalam upaya pengembangan kecakapan kepemimpinan pekerja sedang berjalan walaupun belum maksimal. Maka dalam kepemimpinan periode ini difokuskan dan dibutuhkan sebuah model atau konsep untuk diterapkan oleh Badan Pengurus Daerah Pontianak sebagai pemimpin yang mengarahkan para pekerja atau gembala-gembala yang sedang melaksanakan tugas pelayanan di lingkungan Gereja Kemah Injil Indonesia Daerah Pontianak. Hal-hal yang dilakukan adalah dengan memberikan seminar, pembimbingan bahkan pendampingan bagi pekerja yang sedang dalam pelayanan di lapangan karena semua para pekerja atau gembala sidang membutuhkan mentoring atau bimbingan dari Badan Pengurus Daerah untuk dapat melaksanakan pelayanan dan memaksimalkan potensi yang ada dalam diri pekerja di lingkungan Gereja Kemah Injil Indonesia Daerah Pontianak guna meningkatkan pengembangan pelayanan di kota Pontianak dan sekitarnya. ${ }^{7}$

${ }^{4}$ Indra Gamayanto, "Pengembangan Mentoring Management Dalam Menghasilkan High Quality Human Resource di Tingkat Universitas Dalam Menghadapi masyarakat Ekonomi Asean (MEA) Dengan Menngunakan Konsep Kiyosaki dan Blanchard ABCD Trust Methods-HSOVA," Jurnal Manajemen 13, No 2 (November 2016):162.

${ }^{5}$ Alivia Hermastuti \& Agus Frianto, "Pengaruh Pengembangan dan Motivasi Terhadap Kinerja karyawan di PDAM Kota Madium," Jurnal Ilmu Manajemen 1, No. 3 (Mei 2013):690; Qaisar Abbas, Sara Yaqoob. "Effect of Leadership Development on Employee Performance in Pakistan," Pakistan Economic and Social Review 47, No. 2 (2009):269.

${ }^{6}$ Herdy N. Hutabarat, Mentoring dan Pemuridan (Bandung: Kalam Hidup, 2011), 27.

${ }^{7}$ Edi Kusnadi, Wawancara Oleh Penulis, Pontianak, 17 April 2018. 
Maka pertanyaan yang ingin dijawab penulis adalah: Pertama, bagaimana pengaruh model mentoring Robert Clinton terhadap pengembangan kecakapan kepemimpinan pekerja? Kedua, bagaimana penerapan model mentoring Robert Clinton terhadap pengembangan kecakapan kepemimpinan pekerja dan implementasinya bagi Gereja Kemah Injil Indonesia Daerah Pontianak Kalimantan Barat.

\section{Kajian Teori}

\section{Proses Mentoring Bagi Pengembangan Kepemimpinan Menurut Robert Clinton}

Menurut Robert Clinton ada lima fase dasar pengembangan kepemimpinan. Robert Clinton dalam bukunya membuat sebuah garis kehidupan sebagai sebuah alat dan dasar yang penting untuk menganalisis kehidupan seorang pemimpin yang digambarkan di bawah ini sebagai berikut: ${ }^{8}$

Fase I: Fondasi yang Berdaulat. Fase ini dimulai saat dilahirkan." Dalam fase ini Allah terlibat secara aktif dalam proses mentoring, dan langsung mempersiapkan dan mengembangkan seorang pemimpin menjadi seperti yang dikehendaki dan direncanakan-Nya untuk memimpin umat-Nya. Robert Clinton menegaskan pula bahwa: Allah sedang meletakkan fondasi di dalam pemimpin dan dikontrol dalam kedaulatan-Nya. ${ }^{10}$

Fase II: Pertumbuhan Manusia Batiniah. Robert Clinton menegaskan bahwa: "Sejalan dalam pertumbuhannya dalam kepekaan, pengertian dan ketaatan, ia mengalami masa percobaan. Pengujianpengujian awal ini merupakan pengalaman kritis yang Allah gunakan untuk mempersiapkan pemimpin pada langkah berikutnya di dalam kepemimpinan. Pemimpin yang bertumbuh tanpa kecuali terlibat dalam beberapa bentuk pelayanan. Dalam konteks belajar dengan melakukan ini, dia mendapat pelajaran kehidupan manusia batiniah yang baru."”

Fase III: Pendewasaan Pelayanan. Pada fase ini proses kehidupan seorang pemimpin akan terlihat dalam kaitannya dengan relasi sosialnya. "Dia mulai mencoba-coba dengan karunia rohani walaupun dia belum mengetahui doktrin tentang hal tersebut. Bisa jadi dia mendapat latihan untuk bisa lebih efektif. Pelayanan merupakan fokus dari pemimpin yang menanjak pada tingkat ini. Banyak dari pelajaran yang dia terima akan

${ }^{8}$ Robert Clinton, Pembentukan Pemimpin Sejati (Jakarta: Metanoia, 2004), 15.

${ }^{9}$ Robert Clinton, Pengembangan Kepemimpinan (Bandung: Lembaga Pelayanan Rohani Para Navigator Indonesia, 1992), 33.

${ }^{10}$ Robert Clinton, Pengembangan Kepemimpinan, 33.

${ }^{11}$ Robert Clinton, Pengembangan Kepemimpinan, 33. 
diarahkan kepada hubungan dia dengan orang lain atau kelemahankelemahan kehidupan pribadinya."12

Fase IV: Pendewasaan Kehidupan. Dalam fase ini seorang pemimpin tersebut telah mengenali dan sedang menggunakan karunianya di dalam suatu pelayanan yang memusatkannya. Pemimpin mendapatkan arti dari prioritas sehubungan dengan penggunaan yang terbaik dari karunianya dan mengalami bahwa belajar apa yang tidak harus dilakukan adalah sama pentingnya dengan mempelajari apa yang harus dilakukan."13

Fase V: Konvergensi. Di sini pemimpin mempersembahkan yang terbaik dari dirinya demi kesuksesan dalam pelayanan yang diemban. "Allah menggerakkan dan menempatkan pemimpin kepada suatu peranan yang sesuai dengan campuran karunia dan pengalamannya sehingga pelayanannya dimaksimumkan. Pemimpin tersebut mempergunakan yang terbaik yang ia bisa tawarkan dan dibebaskan dari pelayanan yang ia tidak cocok dan tidak mempunyai karunia di sana."14

Konsep Pengembangan Kecakapan Kepemimpinan Pekerja Kecakapan Kepemimpinan dalam Kaitannya dengan Pengetahuan

Kecakapan kepemimpinan dalam kaitannya dengan pengetahuan terdiri dari tiga bagian penting yang harus dimiliki oleh seorang pemimpin dalam melaksanakan tugas kepemimpinannya. Ketiga kecakapan kepemimpinan tersebut adalah: Pertama, pengetahuan faktual yaitu pengetahuan yang berupa potongan-potongan informasi yang terpisah-pisah atau unsur dasar yang ada dalam suatu displin ilmu tertentu. ${ }^{15}$ Kedua, pengetahuan konseptual adalah pengetahuan yang dimiliki seseorang tentang sesuatu fakta-fakta, konsep-konsep, definisidefinisi serta rumus. ${ }^{16}$ Ketiga, pengetahuan prosedural adalah pengetahuan tentang bagaimana melakukan sesuatu..$^{17}$

\section{Kecakapan Kepemimpinan dalam Kaitannya dengan Budaya Organisasi}

Ada beberapa hal yang penting yang harus dimiliki dan dikuasai oleh seorang pemimpin dalam kaitannya dengan budaya organisasi. Halhal penting tersebut, yaitu: terampil untuk mengelola budaya organisasi,

\footnotetext{
${ }^{12}$ Robert Clinton, Pengembangan Kepemimpinan, 34.

${ }^{13}$ Robert Clinton, Pengembangan Kepemimpinan, 34.

${ }^{14}$ Robert Clinton, Pengembangan Kepemimpinan, 34.

${ }^{15}$ Loorin W. Anderson \& David R. Karthohl, Kerangka Landasan Untuk Pembelajaran, Pengajaran, dan Asesmen: Revisi Taksonomi Pendidikan Bloom (Yogyakarta: Pustaka Pelajar, 2010), 46.

${ }^{16}$ Anderson \& Karthohl, 46.

${ }^{17}$ Anderson \& Karthohl, 77.
} 
terampil mengelola informasi organisasi (Information Management Skill), terampil mengelola komunikasi (Communication Management Skill), terampil mengelola hidup (Self Management Skill), terampil menyelesaikan masalah (Problem Solving Skill), terampil membuat keputusan (Decision Making Management Skill).

\section{Kecakapan Kepemimpinan dalam Kaitannya dengan Potensi dan Sikap}

Herdy N. Hutabarat dalam bukunya Mentoring e Pemuridan, terkait dengan potensi, menulis demikian: "Menurut survei tentang potensi manusia, diperkirakan bahwa rata-rata $10-15 \%$ dari seluruh potensi maksimum manusia yang sempat digunakan seumur hidupnya. Dengan kata lain, masih banyak, sekitar 85 sampai dengan $90 \%$, potensi manusia yang selama ini terbuang atau belum digunakan sama sekali."18 Kecakapan kepemimpinan dalam kaitannya dengan potensi dan sikap mencakup beberapa hal, yaitu: kompetensi, komitmen, kasih, jujur, bertanggung jawab, motivasi, disiplin diri, rendah hati.

\section{Metode}

Penelitian kuantitatif dengan analisis data menggunakan analisis regresi linear berganda, analisis korelasi, dan koefisien determinasi. Analisis regresi linier sederhana adalah analisis yang digunakan peneliti, bila bermaksud meramalkan bagaimana keadaan (naik turunnya) variabel dependen, bila terdapat dua atau lebih variabel independen sebagai faktor prediktor yang dimanipulasi (dinaik turunkan nilainya). ${ }^{19}$ Analisis regresi linier berganda digunakan dalam penelitian ini dengan tujuan untuk membuktikan hipotesis mengenai pengaruh variabel dimensi-dimensi model mentoring Robert Clinton secara parsial maupun secara bersama-sama terhadap kecakapan kepemimpinan.

Analisis korelasi bertujuan untuk mengukur kekuatan asosiasi (hubungan) linier antara dua variabel. Korelasi tidak menunjukkan hubungan fungsional atau dengan kata lain analisis korelasi tidak membedakan antara variabel dependen dengan variabel independen. ${ }^{20}$

Koefisien Determinasi $\left(\mathrm{R}^{2}\right)$ pada intinya mengukur seberapa jauh kemampuan model dalam menerangkan variansi variabel independen. Nilai koefisien determinasi adalah antara nol dan satu. Nilai $\mathrm{R}^{2}$ yang kecil berarti kemampuan variabel-variabel independen dalam

${ }^{18}$ Herdy N. Hutabarat, Mentoring e Pemuridan (Bandung: Kalam Hidup, 2011), 27.

${ }^{19}$ Sugiyono, Metode Penelitian Pendidikan Pendekatan Kuantitatif, Kualitatif dan R $\sim D$ (Bandung: Alfabeta, 2010), 277.

${ }^{20}$ Imam Ghozali, Aplikasi Analisis Multivariate dengan Program IBM SPSS (Yogayakarta: Universitas Diponegoro, 2012), 96. 
menjelaskan variabel dependen sangat terbatas. Nilai yang mendekati satu berarti variabel-variabel independen menberikan hampir semua informasi yang dibutuhkan untuk memprediksi variasi variabel dependen. ${ }^{21}$ Koefisien determinasi ini digunakan untuk mengetahui seberapa besar pengaruh variabel-variabel bebas terhadap variabel terikatnya. Nilai koefisien determinasi ditentukan dengan nilai R square. ${ }^{22}$

\section{Hasil dan Pembahasan}

\section{Profil Responden Penelitian}

Pihak yang menjadi responden adalah para pekerja di lingkungan Gereja Kemah Injil Indonesia Daerah Pontianak. Survei yang dilakukan dengan penyebaran kuesioner, dengan tujuan untuk mengetahui siapa responden, apa yang dipikir, rasakan atau kecenderungan suatu tindakan. Jumlah responden terdiri dari empat puluh satu orang pekerja yang dijadikan sampel dalam penelitian.

\section{Pengujian Instrumen Penelitian}

\section{Tanggapan Responden Tentang Variabel X}

Model mentoring Robert Clinton menunjukkan melakukan fondasi yang berdaulat, pertumbuhan manusia batiniah, pendewasaan pelayanan, pendewasaan kehidupan dan konvergensi adalah merupakan bentuk dari bukti nyata dari kemungkinan akan tingginya model mentoring Robert Clinton yang diberikan oleh pekerja di lingkungan Gereja Kemah Injil Indonesia daerah Pontianak. Penelitian ini menggunakan 50 item kuesioner model mentoring Robert Clinton untuk mengukur persepsi pekerja mengenai model mentoring Robert Clinton yang diberikan oleh Pekerja di Lingkungan Gereja Kemah Injil Indonesia Daerah Pontianak Kalimantan Barat.

Hasil tanggapan responden tertinggi terdapat pada item 18 yang menyatakan bahwa seorang pemimpin mempraktikkan kasih dan pengampunan setiap saat dengan nilai rata-rata sebesar 4,49 yang berarti dalam kategori baik, sedangkan tanggapan responden terendah terdapat pada item 5 yang menyatakan bahwa melalui mentor Allah memegang kendali atas semua peristiwa dalam hidup seorang pemimpin sebesar 3.36 yang berarti kategori baik. Nilai rata-rata tanggapan responden terhadap variabel model mentoring Robert Clinton secara keseluruhan sebesar 4.17 yang bernilai kategori baik.

${ }^{21}$ Imam Ghozali, Aplikasi Analisis Multivariate Dengan Progran IBM SPSS 17 (Semarang: Universitas Diponegoro, 2011), 97.

22 Jonathan Sarwono, Analisis Jalur untuk Riset Bisnis dengan SPSS (Yogyakarta: ANDI Offset, 2007). 


\section{Tanggapan Responden Tentang Variabel (Y)}

Pengembangan kecakapan kepemimpinan pekerja ditunjukkan dengan parameter pengetahuan, organisasi dan gaya kepemimpinan adalah merupakan bentuk dari bukti nyata dari kemungkinan akan tingginya Pengembangan Kecakapan Kepemimpinan yang diberikan oleh pekerja. Penelitian ini menggunakan 53 item kuesioner pengembangan kecakapan kepemimpinan pekerja untuk mengukur persepsi pekerja mengenai pengembangan kecakapan kepemimpinan pekerja yang diberikan oleh pekerja di lingkungan Gereja Kemah Injil Indonesia Daerah Pontianak Kalimantan Barat.

Hasil tanggapan responden mengenai pengembangan kecakapan kepemimpinan pekerja adalah tanggapan responden tertinggi terdapat pada item 53 yang menyatakan bahwa rendah hati adalah sikap yang dikehendaki oleh Tuhan dari setiap pemimpin dengan nilai rata-rata sebesar 4.56 yang berarti dalam kategori sangat baik dan tanggapan responden terendah terdapat pada item 22 menyatakan bahwa pemimpin saya selalu mengawasi apa yang bawahan kerjakan dengan nilai rata-rata sebesar 3.85 yang berarti dalam kategori baik. Nilai ratarata tanggapan reponden terhadap variabel Pengembangan Kecakapan Kepemimpinan secara keseluruhan sebesar 4.19 yang berarti dalam kategori baik.

Analisis Regresi Linier Sederhana

Tabel 1. Hasil Analisis Regresi Linier Sederhana

\begin{tabular}{|c|c|c|c|c|c|c|}
\hline \multicolumn{7}{|c|}{ Coefficients $^{\mathrm{a}}$} \\
\hline & & \multicolumn{2}{|c|}{$\begin{array}{c}\text { Unstandardized } \\
\text { Coefficients }\end{array}$} & \multirow{2}{*}{$\begin{array}{c}\begin{array}{c}\text { Standardized } \\
\text { Coefficients }\end{array} \\
\text { Beta }\end{array}$} & \multirow[b]{2}{*}{$\mathrm{t}$} & \multirow[b]{2}{*}{ Sig. } \\
\hline \multicolumn{2}{|c|}{ Model } & B & Std. Error & & & \\
\hline \multirow[t]{2}{*}{1} & (Constant) & 109.519 & 25.483 & & 4.298 & .000 \\
\hline & $\begin{array}{l}\text { Model Mentoring } \\
\text { Robert Clinton }\end{array}$ & .541 & .122 & .579 & 4.440 & .000 \\
\hline
\end{tabular}

a. Dependent Variabel: Kecakapan Kepemimpinan

Model persamaan regresi yang dapat ditulis dari hasil tersebut dalam bentuk persamaan regresi sebagai berikut: $\mathrm{Y}=0.579 \mathrm{X}_{\mathrm{l}}$. Persamaan regresi tersebut dapat dijelaskan sebagai berikut:

a. Koefisien regresi variabel Model Mentoring Robert Clinton sebesar 0.579 menunjukkan bahwa semakin tinggi tanggapan responden terhadap model mentoring Robert Clinton semakin tinggi pula kecakapan kepemimpinan pekerja. Inteprestasi dari persamaan di atas adalah bahwa koefisien regresi variabel Model mentoring Robert Clinton (X) memiliki tanda positif (0579), yaitu mengandung implikasi bahwa 
model mentoring Robert Clinton searah dengan variabel pengembangan kecakapan kepemimpinan pekerja, dengan kata lain bahwa variabel model mentoring Robert Clinton mempunyai pengaruh yang positif terhadap pengembangan kecakapan kepemimpinan pekerja.

Koefisien Determinasi

Tabel 2. Nilai Koefisien Determinasi

Model Summary ${ }^{\mathrm{b}}$

\begin{tabular}{|c|c|c|c|c|}
\hline Model & $\mathrm{R}$ & R Square & $\begin{array}{l}\text { Adjusted R } \\
\text { Square }\end{array}$ & Std. Error of the Estimate \\
\hline 1 & $.579^{a}$ & .336 & .319 & 13.75424 \\
\hline
\end{tabular}

a. Predictors: (Constant), Model Mentoring Robert Clinton

b. Dependent Variabel: Kecakapan Kepemimpinan

Berdasarkan informasi pada tabel 2 diketahui nilai koefisien determinasi atau $\mathrm{R}^{2}$ sebesar 0,336 artinya bahwa 33,60 \% kecakapan kepemimpinan dipengaruhi oleh variabel bebas yang terdiri dari model mentoring Robert Clinton sedangkan sisanya 66,40 \% dipengaruhi oleh variabel-variabel lainnya yang tidak termasuk dalam penelitian ini. Kebermaknaan dari nilai tersebut memiliki implikasi bahwa variabel model mentoring Robert Clinton terhadap pengembangan kecakapan kepemimpinan pekerja di lingkungan Gereja Kemah Injil Indonesia daerah Pontianak sebesar 33,60 \%, dan sisanya 66,40\% dipengaruhi variabel-variabel lain di luar model yang dimasukan dalam penelitian ini.

Koefisien Korelasi (R)

Tabel 3. Koefisien Korelasi

\begin{tabular}{llrr}
\hline \multicolumn{3}{c}{ Correlations } \\
\hline & & $\begin{array}{c}\text { Model Mentoring } \\
\text { Robert Clinton }\end{array}$ & $\begin{array}{c}\text { Kecakapan } \\
\text { Kepemimpinan }\end{array}$ \\
\hline Model Mentoring & PearsonCorrelation & 1 & $.579^{* *}$ \\
Robert Clinton & Sig. (2-tailed) & & .000 \\
& $\mathrm{~N}$ & 41 & 41 \\
Kecakapan & PearsonCorrelation & $.579^{* *}$ & 1 \\
Kepemimpinan & Sig. (2-tailed) & .000 & 41 \\
& $\mathrm{~N}$ & 41 & \\
\hline
\end{tabular}

**. Correlation is significant at the 0.01 level (2-tailed).

Dari hasil di atas diketahui bahwa kedua variabel memiliki korelasi yang signifikan terhadap antara variabel yang dilihat dari sig. (2-tailed) $0.000<0.050$ berarti terdapat korelasi yang signifikan dan memiliki nilai 
yang cukup berhubungan. Dari hasil perhitungan dapat disimpulkan hipotesis alternatif $(\mathrm{Ha})$ diterima yaitu dengan hubungan positif yang signifikan antara model mentoring Robert Clinton (X) dengan pengembangan kecakapan kepemimpinan pekerja di Gereja Kemah Injil Indonesia Daerah Pontianak.

Tabel 4. Korelasi Indikator Variabel Fondasi yang Berdaulat

\begin{tabular}{|c|c|c|c|c|c|c|}
\hline \multicolumn{7}{|c|}{ Correlations } \\
\hline & & $\begin{array}{l}\text { Fondasi } \\
\text { yang } \\
\text { berdaulat }\end{array}$ & $\begin{array}{l}\text { Pengeta- } \\
\text { huan }\end{array}$ & $\begin{array}{l}\text { Organi- } \\
\text { sasi }\end{array}$ & $\begin{array}{c}\text { Gaya } \\
\text { kepemim- } \\
\text { pinan }\end{array}$ & $\begin{array}{c}\text { Potensi } \\
\text { dan } \\
\text { sikap }\end{array}$ \\
\hline \multirow[t]{3}{*}{$\begin{array}{l}\text { Fondasi yang } \\
\text { berdaulat }\end{array}$} & $\begin{array}{l}\text { Pearson } \\
\text { Correlation }\end{array}$ & 1 & .188 & .280 & $.393^{*}$ & .301 \\
\hline & $\begin{array}{l}\text { Sig. (2- } \\
\text { tailed) }\end{array}$ & & .238 & .076 & .011 & .056 \\
\hline & $\mathrm{N}$ & 41 & 41 & 41 & 41 & 41 \\
\hline \multirow[t]{3}{*}{ Pengetahuan } & $\begin{array}{l}\text { Pearson } \\
\text { Correlation }\end{array}$ & .188 & 1 & $.730^{* *}$ & $.377^{*}$ & $.387^{*}$ \\
\hline & $\begin{array}{l}\text { Sig. }(2- \\
\text { tailed) }\end{array}$ & .238 & & .000 & .015 & .012 \\
\hline & $\mathrm{N}$ & 41 & 41 & 41 & 41 & 41 \\
\hline \multirow[t]{3}{*}{ Organisasi } & $\begin{array}{l}\text { Pearson } \\
\text { Correlation }\end{array}$ & .280 & $.730^{* *}$ & 1 & $.578^{* *}$ & $.419^{* *}$ \\
\hline & $\begin{array}{l}\text { Sig. (2- } \\
\text { tailed) }\end{array}$ & .076 & .000 & & .000 & .006 \\
\hline & $\mathrm{N}$ & 41 & 41 & 41 & 41 & 41 \\
\hline \multirow[t]{3}{*}{$\begin{array}{l}\text { Gaya } \\
\text { kepemimpinan }\end{array}$} & $\begin{array}{l}\text { Pearson } \\
\text { Correlation }\end{array}$ & $.393^{*}$ & $.377^{*}$ & $.578^{* *}$ & 1 & $.667^{* *}$ \\
\hline & $\begin{array}{l}\text { Sig. (2- } \\
\text { tailed) }\end{array}$ & .011 & .015 & .000 & & .000 \\
\hline & $\mathrm{N}$ & 41 & 41 & 41 & 41 & 41 \\
\hline \multirow[t]{3}{*}{$\begin{array}{l}\text { Potensi dan } \\
\text { sikap }\end{array}$} & $\begin{array}{l}\text { Pearson } \\
\text { Correlation }\end{array}$ & .301 & $.387^{*}$ & $.419^{* *}$ & $.667^{* *}$ & 1 \\
\hline & $\begin{array}{l}\text { Sig. (2- } \\
\text { tailed) }\end{array}$ & .056 & .012 & .006 & .000 & \\
\hline & $\mathrm{N}$ & 41 & 41 & 41 & 41 & 41 \\
\hline
\end{tabular}

*. Correlation is significant at the 0.05 level (2-tailed).

**. Correlation is significant at the 0.01 level (2-tailed).

Berdasarkan tabel 4, hasil pengolahan data menjelaskan bahwa fondasi yang berdaulat memengaruhi Variabel Terikat Secara berurutan 
yaitu: Pertama, fondasi yang berdaulat mempunyai pengaruh terkuat ke gaya kepemimpinan dengan nilai 0.393. Kedua, fondasi yang berdaulat selanjutnya memengaruhi potensi dan sikap dengan nilai 0.301. Ketiga, fondasi yang berdaulat selanjutnya memengaruhi organisasi dengan nilai 0.280. Keempat, fondasi yang berdaulat selanjutnya memengaruhi pengetahuan dengan nilai 0.188 .

Dengan demikian nilai tertinggi hubungan variabel bebas adalah pengaruh indikator fondasi yang berdaulat dengan variabel terikat yaitu gaya kepemimpinan dengan nilai 0,393. Hal ini menyimpulkan bahwa pekerja di lingkungan Gereja Kemah Injil Indonesia daerah Pontianak menyadari bahwa mentoring sangat penting untuk diimplementasikan oleh seorang pemimpin. Sedangkan skor terendah adalah hubungan variabel bebas yaitu pengaruh indikator pertumbuhan batiniah dengan variabel terikat yaitu gaya kepemimpinan. Hal ini menyimpulkan bahwa pekerja lingkungan Gereja Kemah Injil Indonesia daerah Pontianak belum menyadari bahwa tugas mentoring adalah melaksanakan kehendak Allah atas lahirnya seorang pemimpin baru.

Tabel 5. Korelasi Pertumbuhan Batiniah

Correlations

\begin{tabular}{|c|c|c|c|c|c|c|}
\hline & & $\begin{array}{l}\text { Pertum- } \\
\text { buhan } \\
\text { manusia } \\
\text { batiniah }\end{array}$ & $\begin{array}{l}\text { Penge- } \\
\text { tahuan }\end{array}$ & $\begin{array}{l}\text { Organi- } \\
\text { sasi }\end{array}$ & $\begin{array}{c}\text { Gaya } \\
\text { kepemim- } \\
\text { pinan }\end{array}$ & $\begin{array}{l}\text { Potensi dan } \\
\quad \text { sikap }\end{array}$ \\
\hline \multirow{3}{*}{$\begin{array}{l}\text { Pertum- } \\
\text { buhan } \\
\text { manusia } \\
\text { batiniah }\end{array}$} & $\begin{array}{l}\text { Pearson } \\
\text { Correlation }\end{array}$ & l & .180 & $.312^{*}$ & $.359^{*}$ & $.339^{*}$ \\
\hline & Sig. (2-tailed) & & .261 & .047 & .021 & .030 \\
\hline & $\mathrm{N}$ & 41 & 41 & 41 & 41 & 41 \\
\hline \multirow[t]{3}{*}{$\begin{array}{l}\text { Pengeta- } \\
\text { huan }\end{array}$} & $\begin{array}{l}\text { Pearson } \\
\text { Correlation }\end{array}$ & .180 & 1 & $.730^{* *}$ & $.377^{*}$ & $.387^{*}$ \\
\hline & Sig. (2-tailed) & .261 & & .000 & .015 & .012 \\
\hline & $\mathrm{N}$ & 41 & 41 & 41 & 41 & 41 \\
\hline \multirow[t]{3}{*}{ Organisasi } & $\begin{array}{l}\text { Pearson } \\
\text { Correlation }\end{array}$ & $.312^{*}$ & $.730^{* *}$ & 1 & $.578^{* *}$ & $.419^{* *}$ \\
\hline & Sig. (2-tailed) & .047 & .000 & & .000 & .006 \\
\hline & $\mathrm{N}$ & 41 & 41 & 41 & 41 & 41 \\
\hline \multirow{3}{*}{$\begin{array}{l}\text { Gaya } \\
\text { kepemim- } \\
\text { pinan }\end{array}$} & $\begin{array}{l}\text { Pearson } \\
\text { Correlation }\end{array}$ & $.359^{*}$ & $.377^{*}$ & $.578^{* *}$ & 1 & $.667^{* *}$ \\
\hline & Sig. (2-tailed) & .021 & .015 & .000 & & .000 \\
\hline & $\mathrm{N}$ & 41 & 41 & 41 & 41 & 41 \\
\hline $\begin{array}{l}\text { Potensi dan } \\
\text { sikap }\end{array}$ & $\begin{array}{l}\text { Pearson } \\
\text { Correlation }\end{array}$ & $.339^{*}$ & $.387^{*}$ & $.419^{* *}$ & $.667^{* *}$ & 1 \\
\hline
\end{tabular}




\begin{tabular}{lrrrrr} 
Sig. (2-tailed) & .030 & .012 & .006 & .000 & \\
$\mathrm{~N}$ & 41 & 41 & 41 & 41 & 41 \\
\hline
\end{tabular}

*. Correlation is significant at the 0.05 level (2-tailed).

**. Correlation is significant at the 0.01 level (2-tailed).

Berdasarkan tabel 5 di atas hasil pengolahan data sebagaimana tampak pada tabel menjelaskan bahwa pertumbuhan manusia batiniah memengaruhi variabel terikat secara berurutan yaitu: Pertama, pertumbuhan manusia batiniah mempunyai pengaruh terkuat ke gaya kepemimpinan dengan nilai 0.359. Kedua, pertumbuhan manusia batiniah selanjutnya memengaruhi potensi dan sikap dengan nilai 0.339. Ketiga, pertumbuhan manusia batiniah selanjutnya memengaruhi organisasi dengan nilai 0.312. Keempat, pertumbuhan manusia batiniah selanjutnya memengaruhi pengetahuan dengan nilai 0.180.

Dengan demikian nilai tertinggi hubungan variabel bebas adalah pengaruh indikator pertumbuhan batiniah dengan variabel terikat yaitu gaya kepemimpinan dengan nilai 0,359 . Hal ini menyimpulkan bahwa pekerja di lingkungan Gereja Kemah Injil Indonesia daerah Pontianak hendaknya mempraktikkan kasih dan pengampunan setiap saat dalam pengembangan kecakapan kepemimpinan pekerja. Sedangkan skor terendah adalah hubungan variabel bebas yaitu pengaruh indikator pertumbuhan batiniah dengan variabel terikat yaitu pengetahuan dan nilai. Hal ini menyimpulkan bahwa pekerja lingkungan Gereja Kemah Injil Indonesia daerah Pontianak belum menyadari ujian kepemimpinan merupakan sarana yang dipakai oleh Allah untuk mengembangkan sikap seorang pemimpin.

Tabel 6. Pendewasaan Pelayanan

Correlations

\begin{tabular}{|c|c|c|c|c|c|c|}
\hline & & $\begin{array}{l}\text { Pendewa- } \\
\text { saan } \\
\text { pelayanan }\end{array}$ & $\begin{array}{l}\text { Pengeta- } \\
\text { huan }\end{array}$ & $\begin{array}{l}\text { Organi- } \\
\text { sasi }\end{array}$ & $\begin{array}{c}\text { Gaya } \\
\text { kepemim- } \\
\text { pinan }\end{array}$ & $\begin{array}{c}\text { Potensi } \\
\text { dan sikap }\end{array}$ \\
\hline \multirow{3}{*}{$\begin{array}{l}\text { Pendewa- } \\
\text { saan } \\
\text { pelayanan }\end{array}$} & $\begin{array}{l}\text { Pearson } \\
\text { Correlation }\end{array}$ & 1 & $481^{* *}$ & $.538^{* *}$ & $.426^{* *}$ & $.564^{* *}$ \\
\hline & Sig. (2-tailed) & & .001 & .000 & .005 & .000 \\
\hline & $\mathrm{N}$ & 41 & 41 & 41 & 41 & 41 \\
\hline \multirow[t]{3}{*}{$\begin{array}{l}\text { Pengetah } \\
\text { u-an }\end{array}$} & $\begin{array}{l}\text { Pearson } \\
\text { Correlation }\end{array}$ & $.481^{*^{* *}}$ & 1 & $.730^{* *}$ & $.377^{*}$ & $.387^{*}$ \\
\hline & Sig. (2-tailed) & .001 & & .000 & .015 & .012 \\
\hline & $\mathrm{N}$ & 41 & 41 & 41 & 41 & 41 \\
\hline Organisas & $\begin{array}{l}\text { Pearson } \\
\text { Correlation }\end{array}$ & $.538^{* *}$ & $.730^{* *}$ & 1 & $.578^{* *}$ & $.419^{* *}$ \\
\hline
\end{tabular}




$\begin{array}{llrrrrr}\text { i } & \text { Sig. (2-tailed) } & .000 & .000 & & .000 & .006 \\ & \text { N } & 41 & 41 & 41 & 41 & 41 \\ \text { Gaya } & \text { Pearson } & .426^{* *} & .377^{*} & .578^{* *} & 1 & .667^{* *} \\ \text { kepemim } & \text { Correlation } \\ \text { pinan } & \text { Sig. (2-tailed) } & .005 & .015 & .000 & & .000 \\ & \mathrm{~N} & 41 & 41 & 41 & 41 & 41 \\ \text { Potensi } & \text { Pearson } & .564^{* *} & .387^{*} & .419^{* *} & .667^{* *} & 1 \\ \text { dan sikap } & \text { Correlation } & & .012 & .006 & .000 & \\ & \text { Sig. (2-tailed) } & .000 & .012 & 41 & 41 & 41 \\ & \text { N } & 41 & 41 & 41 & \end{array}$

**. Correlation is significant at the 0.01 level (2-tailed).

*. Correlation is significant at the 0.05 level (2-tailed).

Berdasarkan tabel 6 di atas menjelaskan bahwa pendewasaan pelayanan memengaruhi variabel terikat secara berurutan yaitu: Pertama, pendewasaan pelayanan mempunyai pengaruh terkuat ke potensi dan sikap dengan nilai 0.564 . Kedua pendewasaan pelayanan selanjutnya memengaruhi organisasi dengan nilai 0.538. Ketiga pendewasaan pelayanan selanjutnya memengaruhi pengetahuan dengan nilai 0.481 . Keempat, pendewasaan pelayanan selanjutnya memengaruhi gaya kepemimpinan dengan nilai 0.426 .

Dengan demikian nilai tertinggi hubungan variabel bebas adalah pengaruh variabel pendewasaan pelayanan dengan variabel terikat yaitu potensi dan sikap dengan nilai 0,564. Hal ini menyimpulkan bahwa pekerja di lingkungan Gereja Kemah Injil Indonesia daerah Pontianak adalah seorang pemimpin membangun relasi yang luas guna mengembangkan organisasinya. Sedangkan skor terendah adalah hubungan variabel bebas yaitu pengaruh variabel pendewasaan pelayanan dengan variabel terikat yaitu gaya kepemimpinan deengan nilai 0.426. Hal ini menyimpulkan bahwa pekerja lingkungan Gereja Kemah Injil Indonesia daerah Pontianak belum menyadari bahwa dalam melayani menghormati pemimpin yang di atas dan mengangkat orangorang yang dipimpin.

Tabel 7. Pendewasaan Hidup

\begin{tabular}{llllllll}
\hline \multicolumn{1}{c}{ Correlations } \\
\hline & $\begin{array}{c}\text { Pende- } \\
\text { wasaan } \\
\text { kehi- } \\
\text { dupan }\end{array}$ & $\begin{array}{c}\text { Penge- } \\
\text { tahuan }\end{array}$ & Organi-sasi & $\begin{array}{c}\text { Gaya } \\
\text { kepemim- } \\
\text { pinan }\end{array}$ & $\begin{array}{c}\text { Potensi } \\
\text { dan sikap }\end{array}$ \\
\hline $\begin{array}{l}\text { Pende- } \\
\text { wasaan }\end{array}$ & $\begin{array}{l}\text { Pearson } \\
\text { Correlation }\end{array}$ & & 1 & $.416^{* *}$ & $.355^{*}$ & .205 & $.530^{* *}$
\end{tabular}




\begin{tabular}{|c|c|c|c|c|c|c|}
\hline kehidupan & Sig. (2-tailed) & & .007 & .023 & .198 & .000 \\
\hline & $\mathrm{N}$ & 41 & 41 & 41 & 41 & 41 \\
\hline $\begin{array}{l}\text { Pengeta- } \\
\text { huan }\end{array}$ & $\begin{array}{l}\text { Pearson } \\
\text { Correlation }\end{array}$ & $.416^{* *}$ & 1 & $.730^{* *}$ & $.377^{*}$ & $.387^{*}$ \\
\hline & Sig. (2-tailed) & .007 & & .000 & .015 & .012 \\
\hline & $\mathrm{N}$ & 41 & 41 & 41 & 41 & 41 \\
\hline Organisasi & $\begin{array}{l}\text { Pearson } \\
\text { Correlation }\end{array}$ & $.355^{*}$ & $.730^{* *}$ & 1 & $.578^{* *}$ & $.419^{* *}$ \\
\hline & Sig. (2-tailed) & .023 & .000 & & .000 & .006 \\
\hline & $\mathrm{N}$ & 41 & 41 & 41 & 41 & 41 \\
\hline $\begin{array}{l}\text { Gaya } \\
\text { kepemim- }\end{array}$ & $\begin{array}{l}\text { Pearson } \\
\text { Correlation }\end{array}$ & .205 & $.377^{*}$ & $.578^{* *}$ & 1 & $.667^{* *}$ \\
\hline pinan & Sig. (2-tailed) & .198 & .015 & .000 & & .000 \\
\hline & $\mathrm{N}$ & 41 & 41 & 41 & 41 & 41 \\
\hline $\begin{array}{l}\text { Potensi dan } \\
\text { sikap }\end{array}$ & $\begin{array}{l}\text { Pearson } \\
\text { Correlation }\end{array}$ & $.530^{* *}$ & $.387^{*}$ & $.419^{* * *}$ & $.667^{* *}$ & \\
\hline & Sig. (2-tailed) & .000 & .012 & .006 & .000 & \\
\hline & $\mathrm{N}$ & 41 & 41 & 41 & 41 & 1 \\
\hline
\end{tabular}

**. Correlation is significant at the 0.01 level (2-tailed).

*. Correlation is significant at the 0.05 level (2-tailed).

Berdasarkan tabel 7 di atas menjelaskan bahwa pendewasaan hidup memengaruhi variabel terikat secara berurutan yaitu: Pertama, pendewasaan hidup mempunyai pengaruh terkuat ke potensi dan sikap dengan nilai 0.530 . Kedua pendewasaan hidup selanjutnya memengaruhi organisasi dengan nilai 0.355 . Ketiga, pendewasaan hidup selanjutnya memengaruhi pengetahuan dengan nilai 0.416. Keempat, pendewasaan hidup selanjutnya memengaruhi gaya kepemimpinan dengan nilai 0.205.

Dengan demikian nilai tertinggi hubungan variabel bebas adalah pengaruh indikator pendewasaan pelayanan dengan variabel terikat yaitu potensi dan sikap dengan nilai 0,530. Hal ini menyimpulkan bahwa pekerja di lingkungan Gereja Kemah Injil Indonesia daerah Pontianak menyadari bahwa pemimpin terus mencipatkan keintiman dengan Tuhan guna meneguhkan pelayanannya. Sedangkan skor terendah adalah hubungan variabel bebas yaitu pengaruh indikator pendewasaan pelayanan dengan variabel terikat yaitu gaya kepemimpinan. Hal ini menyimpulkan bahwa pekerja di lingkungan Gereja Kemah Injil Indonesia daerah Pontianak belum menyadari setiap proses pendewasaan dalam setiap pelayanannya. 
Tabel 8. Konvergensi

\begin{tabular}{|c|c|c|c|c|c|c|}
\hline \multicolumn{7}{|c|}{ Correlations } \\
\hline & & $\begin{array}{c}\text { Konver- } \\
\text { gensi }\end{array}$ & $\begin{array}{l}\text { Pengeta- } \\
\text { huan }\end{array}$ & $\begin{array}{l}\text { Organi- } \\
\text { sasi }\end{array}$ & $\begin{array}{c}\text { Gaya } \\
\text { kepemim- } \\
\text { pinan }\end{array}$ & $\begin{array}{c}\text { Potensi } \\
\text { dan sikap }\end{array}$ \\
\hline \multirow[t]{3}{*}{ Konvergensi } & $\begin{array}{l}\text { Pearson } \\
\text { Correlation }\end{array}$ & 1 & $.447^{* *}$ & $.358^{*}$ & .108 & $.478^{* *}$ \\
\hline & Sig. (2-tailed) & & .003 & .022 & .501 & .002 \\
\hline & $\mathrm{N}$ & 41 & 41 & 41 & 41 & 41 \\
\hline \multirow[t]{3}{*}{ Pengetahuan } & $\begin{array}{l}\text { Pearson } \\
\text { Correlation }\end{array}$ & $.447^{* *}$ & 1 & $.730^{* *}$ & $.377^{*}$ & $.387^{*}$ \\
\hline & Sig. (2-tailed) & .003 & & .000 & .015 & .012 \\
\hline & $\mathrm{N}$ & 41 & 41 & 41 & 41 & 41 \\
\hline \multirow[t]{3}{*}{ Organisasi } & $\begin{array}{l}\text { Pearson } \\
\text { Correlation }\end{array}$ & $.358^{*}$ & $.730^{* *}$ & 1 & $.578^{* *}$ & $.419^{* *}$ \\
\hline & Sig. (2-tailed) & .022 & .000 & & .000 & .006 \\
\hline & $\mathrm{N}$ & 41 & 41 & 41 & 41 & 41 \\
\hline \multirow{3}{*}{$\begin{array}{l}\text { Gaya } \\
\text { kepemim- } \\
\text { pinan }\end{array}$} & $\begin{array}{l}\text { Pearson } \\
\text { Correlation }\end{array}$ & .108 & $.377^{*}$ & $.578^{* *}$ & 1 & $.667^{* *}$ \\
\hline & Sig. (2-tailed) & .501 & .015 & .000 & & .000 \\
\hline & $\mathrm{N}$ & 41 & 41 & 41 & 41 & 41 \\
\hline \multirow[t]{3}{*}{$\begin{array}{l}\text { Potensi dan } \\
\text { sikap }\end{array}$} & $\begin{array}{l}\text { Pearson } \\
\text { Correlation }\end{array}$ & $.478^{* *}$ & $.387^{*}$ & $.419^{* *}$ & $.667^{* *}$ & 1 \\
\hline & Sig. (2-tailed) & .002 & .012 & .006 & .000 & \\
\hline & $\mathrm{N}$ & 41 & 41 & 41 & 41 & 41 \\
\hline
\end{tabular}

**. Correlation is significant at the 0.01 level (2-tailed).

*. Correlation is significant at the 0.05 level (2-tailed).

Berdasarkan tabel 8 di atas dari pengolahan data menjelaskan bahwa konvergensi memengaruhi variabel terikat secara berurutan yaitu: Pertama, konvergensi mempunyai pengaruh terkuat ke potensi dan sikap dengan nilai 0.478. Kedua, konvergensi selanjutnya memengaruhi pengetahuan dengan nilai 0.447. Ketiga, konvergensi selanjutnya memengaruhi organisasi dengan nilai 0.358. Keempat, konvergensi selanjutnya memengaruhi gaya kepemimpinan dengan nilai 0.108. Dengan demikian nilai tertinggi hubungan variabel bebas adalah pengaruh indikator konvergensi dengan variabel terikat yaitu potensi dan sikap dengan nilai 0,478. Hal ini menyimpulkan bahwa pekerja di lingkungan Gereja Kemah Injil Indonesia daerah Pontianak mempraktikkan firman Tuhan setiap saat dalam pelayanannya. Sedangkan skor terendah adalah hubungan variabel bebas yaitu pengaruh indikator konvergensi dengan variabel terikat yaitu gaya 
kepemimpinan. Hal ini menyimpulkan bahwa pekerja di lingkungan Gereja Kemah Injil Indonesia Daerah Pontianak belum menjadi seorang mentor yang memberi waktu khusus untuk mengembangkan pemimpin baru.

Berdasarkan dari hasil analisis data dan obervasi yang telah dilakukan, dapat diungkapkan pembahasan penelitian pengaruh model mentoring Robert Clinton terhadap pengembangan kecakapan kepemimpinan pekerja di Lingkungan Gereja Kemah Injil Indonesia Daerah Pontianak, maka pada bagian ini akan diuraikan tentang model mentoring Robert Clinton bagi pengembangan kecakapan kepemimpinan pekerja di lingkungan Gereja Kemah Injil Indonesia Daerah Pontianak.

Persepsi pengaruh model mentoring Robert Clinton dari persepsi para responden yang diperoleh hasil angket, menunjukkan bahwa pengaruh model mentoring Robert Clinton terhadap pengembangan kecakapan kepemimpinan pekerja pada kategori baik. Hasil uji hipotesis dengan melakukan uji-t, ditemukan bahwa terdapat pengaruh yang positif dan signifikan antara variabel model mentoring Robert Clinton terhadap pengembangan kecakapan kepemimpinan pekerja di lingkungan Gereja Kemah Injil Indonesia Daerah Pontianak. Hal ini dapat terlihat pada hasil uji-t diperoleh $\mathrm{t}$-hitung sebesar 2,020 dengan tingkat probolitas (sig) adalah nilai $t$ hitung (4.440) lebih besar dari $t$ tabel $(2,020)$ dan nilai signifikan sebesar 0.000 lebih kecil dari 0.05. Hal ini berarti bahwa hipotesis yang diajukan oleh penulis diterima yaitu terdapat pengaruh yang positif dan signifikan antara variabel model mentoring Robert Clinton (X) terhadap pengembangan kecakapan kepemimpinan pekerja di Lingkungan Gereja Kemah Injil Indonesia Daerah Pontianak.

Pengembangan kecakapan kepemimpinan pekerja dalam melaksanakan tugas pelayanan akan terjadi jika adanya peran mentoring bagi pekerja yang memiliki kompetensi, kemampuan serta keahliaan yang tinggi. Jadi model mentoring Robert Clinton yang dilakukan dengan fase pengembangan kecakapan kepemimpinan pekerja akan memberikan dampak dan mempunyai pengaruh yang positif dalam mengembangkan, mempertahankan dan meningkatkan kecakapan kepemimpian pekerja dalam proses pelayanannya.

Setelah analisis data, maka ditemukan data-data tentang hubungan yang kuat antara model mentoring Robert Clinton terhadap pengembangan kecakapan kepemimpinan pekerja, maka bagian ini akan diuraikan tentang aplikasi model mentoring terhadap pengembangan kecakapan kepemimpinan pekerja. Teori-teori baru ini dibangun sebagai hasil kajian dan penelitian yang telah menunjukkan hubungan antara 
variabel dan indikator $X$ yaitu model mentoring Robert Clionton terhadap Y yaitu pengembangan kecakapan kepemimpinan pekerja.

\section{Implementasi Mentoring Dalam Organisasi}

\section{Mempraktikkan Kasih dan Pengampunan Dalam Kepemimpinan}

Dalam kepemimpinan suatu organisasi atau gereja bahwa semua pengikut atau orang-orang yang dipimpin memerlukan kasih. ${ }^{23}$ Dalam konteks kepemimpinan, maka seorang pemimpin harus mengenal kasih Allah yang sempurna kepadanya. Kasih Allah yang sempurna itu ialah pribadi Yesus Kristus sendiri yang perlu dikenal oleh seorang pemimpin. Kasih merupakan kualitas karakter yang harus terus-menerus dikembangkan oleh seorang pemimpin dalam kepemimpinannya. "Kasih adalah yang pertama dan terutama dari keempat kualitas karakter dasar yang penting bagi seorang pemimpin rohani." ${ }^{24}$ Kasih itu menunjukkan perhatian yang tulus dan komitmen untuk melayani atau menolong satu sama lain..$^{25}$ Seorang pemimpin dalam kepemimpinannya harus mengembangkan kehidupan kasih dengan memberi perhatian yang tulus kepada yang dipimpinnya dan bertekad untuk melayani bawahannya serta mengajar para pengikutnya untuk juga saling melayani. Dengan demikian tugas sebagai pemimpin adalah memiliki kebiasaan hidup mengasihi, yaitu mengekspresikan kasih kepada orang-orang yang dipimpin sebagai sebuah model kepemimpinan yang diterapkan.

\section{Membangun Relasi Dalam Kepemimpinan}

Pemimpin yang efektif selalu berupaya memperkuat hubungan sebagai sarana serta tujuan dalam menjalankan kepemimpinannya. Membangun relasi pada semua orang perlu ditingkatkan dalam sebuah organisasi. Puls dkk dalam penelitiannya menjelaskan bahwa cara seorang gembala berelasi dan membangun kepercayaan dengan para pemimpin awam secara terbuka akan menentukan apakah mereka akan memercayai kembali dan bahkan ikut terlibat dalam misi dari pemimpin itu sendiri. ${ }^{26}$ Dengan mengembangkan jaringan relasi baik terhadap organisasi lain maupun terhadap orang-orang yang dipimpin akan meningkatkan semangat dan iklim kerja sebuah organisasi.

${ }^{23}$ Daniel Ronda, Leadership Wisdom (Bandung: Kalam Hidup, 2011), 56.

${ }^{24}$ Tom Yeakley, Character Formation for Leaders (Bandung: Kalam Hidup, 2013), 40.

${ }^{25}$ Tom Yeakley, Character Formation for Leaders, 41.

${ }^{26}$ Timothy R. Puls, Laverne L Ludden, dan James Freemyer, "Authentic Leadership and Its Relationship to Ministerial Effectiveness," Journal of Applied Christian Leadership 8, no. 1 (2014): 13. 


\section{Membangun Keintiman Dengan Tuhan}

Seorang pemimpin yang efektif tentunya akan melaksanakan kepemimpinanya dengan baik yaitu ditandai dengan memelihara suatu hubungan pribadi yang bersemangat dengan Tuhan sampai akhir. Daniel Ronda dalam bukunya Leadership Wisdom memperkenalkan tentang spritualitas klasik. ${ }^{27}$ Yaitu spritualitas yang tetap dipelihara oleh para pemimpin dari sejak awal sejarah gereja, dari zaman ke zaman, yaitu adanya waktu khusus untuk berdoa dam membaca firman Tuhan. Kehidupan rohani sepertinya yang harus ada dan dikembangkan terus menerus oleh seorang pemimpin yang sedang bertumbuh. Kehidupan rohani yang baik dari seorang pemimpin ditandai dengan memiliki hubungan pribadi dengan Allah, yang meliputi mengutamakan Allah dalam setiap bidang hidupnya. Andrew Brake dalam bukunya Spritual Formation mengemukakan beberapa hal untuk mempelajari dan memperoleh sesuatu dari firman Tuhan, yang pertama adalah dengan mendengarkan..$^{28}$ Kedua, membacanya. Ketiga, berinteraksi dengan Kitab Suci. Seorang pemimpin harus mempelajari firman Tuhan sebagau upaya membangun keintiman dengan Tuhan.

\section{Mempraktikkan Firman Tuhan Dalam Kepemimpinannya}

Seorang pemimpin yang efektif ditandai dengan sikap yang kuat terhadap sebuah otoritas rohani sebagai dasar kekuasaan yang utama dalam melaksanakan kepemimpinannya. Proses firman adalah sebuah jenis proses di mana seorang pemimpin menerima firman dari Tuhan yang sangat memengaruhi arah, komitmen, pengambilan keputusan, sistem nilai pribadi, pembentukan kerohanian, otoritas rohani atau filosofi pelayanannya. ${ }^{29}$ Dengan demikian pemimpin akan terus mendapatkan berbagai jenis firman Tuhan sepanjang kehidupannya untuk terus bertumbuh.

\section{Menjadi Pemimpin yang Mendengar}

Sikap untuk mendengar akan menentukan langkah-langkah strategis yang diambil dalam sebuah kepemimpinan. Keinginan untuk belajar dan kemauan untuk menerima nasihat akan mempercepat proses pengembangan kecakapan seorang pemimpin.

Seorang mentee harus memiliki sikap yang terbuka untuk menerima pengarahan, masukan, nasihat, bahkan teguran dari mentornya. Penting sekali bagi seorang mentee untuk memiliki sikap yang senang diajar

${ }^{27}$ Daniel Ronda, Leadership Wisdom (Bandung: Kalam Hidup, 2011), 78.

${ }^{28}$ Andrew Brake, Spritual Formation (Bandung: Kalam Hidup, 2014), 13-16.

${ }^{29}$ Robert Clinton, Pembentukan Pemimpin Sejati (Jakarta: Metanoia, 2004), 205 
(kerendahan hati untuk menerima nasihat). ${ }^{30}$ Pemimpin yang melakukan proses mentoring adalah memberikan contoh teladan yang alkitabiah, membimbing, melatih, dan mengutus sehingga hasil mentoring berdampak untuk menghasilkan para mentor untuk mentee lainnya. ${ }^{31}$

\section{Pemimpin yang Memiliki Kerendahan Hati}

Istilah kerendahan hati sebenarnya berasal dari akar kata humus, yang berarti tanah liat, bumi. Di dalamnya mengandung makna kesediaan menerima pengajaran, fleksibel, lentur, dapat dicetak atau dibentuk ulang-tanah liat dipelarikan sang penjunan (bdg. Yeremia 18). ${ }^{32}$ Seorang pemimpin harus memperhadapkan dan membandingkan dirinya dengan Allah. Tujuannya ialah supaya ia dapat bertumbuh dalam karakter kerendahan hati. "Kerendahan hati yang sejati berasal dari pemahaman terhadap keberadaan kita dalam perbandingannya dengan Allah sendiri". ${ }^{33}$

Dari hasil uji koefesien determinasi pengaruh yang diberikan dari variabel model mentoring Robert Clinton terhadap pengembangan kecakapan kepemimpinan pekerja sebesar 33,60\%, sedangkan sisanya sebesar 66,40\% kecakapan kepemimpinan pekerja dipengaruhi oleh variabel lain seperti budaya organisasi, kondisi ekonomi dan lain sebagainya yang tidak menjadi fokus dalam penelitian ini. Gereja Kemah Injil Indonesia Daerah Pontianak membutuhkan pemimpin yang membangun relasi dalam kepemimpinan, menciptakan keintiman dengan Tuhan, mempraktikkan firman Tuhan dalam kepemimpinanya, menyikap setiap konflik dengan sabar dan bijaksana, pemimpin yang memiliki kerendahan hati. Dari hasil penelitian ini diperoleh bahwa, pengaruh variabel independent terhadap variabel terikat yaitu antara model mentoring Robert Clinton (X) terhadap pengembangan kecakapan kepemimpinan pekerja terdapat pengaruh yang positif dan signifikan.

Dari hasil penelitian yang telah dilakukan, penulis merekomendasikan bahwa model mentoring Robert Clinton merupakan faktor yang penting untuk diimplementasikan di dalam mengembangkan kecakapan kepemimpinan pekerja di lingkungan Gereja Kemah Injil Indonesia Daerah Pontianak guna membawa umat Allah mencapai tujuan yang dikehendaki-Nya melalui seorang pemimpin.

${ }^{30}$ Herdy N. Hutabarat, Mentoring dan Pemuridan (Bandung: Kalam Hidup, 2011), 64.

${ }^{31}$ Agus Prihanto, "Peran Proses Mentoring Pemimpin Kaum Muda Bagi

Perkembangan Pelayanan Pemuda Di Gereja," Jurnal Jaffray 16, no. 2 (6 Oktober 2018):

210, https://doi.org/10.25278/jj7l.vl6i2.258.

32 Darlene Zschech, The Art of Mentoring (Malang: Literatur SAAT, 2013), 118.

33 Tom Yeakley, Character Formation for Leaders, 86. 


\section{Kesimpulan}

Berdasarkan deskripsi masalah penelitian, pembahasan dan analisis hasil penelitian yang diperoleh, maka peneliti menarik beberapa kesimpulan akhir dalam disertasi ini sebagai berikut: Pertama, ditemukan adanya pengaruh yang positif dan signifikan model mentoring Robert Clinton terhadap pengembangan kecakapan kepemimpinan pekerja di lingkungan Gereja Kemah Injil Indonesia Daerah Pontianak Kalimantan Barat, ditunjukkan dengan koefisien korelasi (rxl.y) sebesar 0.050 nilai koefisien determinasi atau $\mathrm{R}^{2}$ sebesar 0,336 artinya bahwa 33,60\% kecakapan kepemimpinan pekerja dipengaruhi oleh variabel bebas yang terdiri dari model mentoring Robert Clinton. Kedua, hasil penelitian ini menunjukkan terdapat pengaruh positif dan signifikan model mentoring Robert Clinton terhadap pengembang-an kecakapan kepemimpinan pekerja di lingkungan Gereja Kemah Injil Indonesia Daerah Pontianak.

Hal ini menunjukkan bahwa kecakapan kepemimpinan pekerja dapat dikembangkan melalui sebuah proses mentoring, maka dipastikan kepemimpinan di lingkungan Gereja Kemah Injil Indonesia daerah Pontianak dapat bertumbuh dengan baik. Dalam tulisan ini penulis memaparkan model mentoring Robert Clinton untuk menjadi acuan dan landasan dalam pengembangan kecakapan kepemimpinan pekerja. Penulis juga memaparkan adanya pengaruh mentoring dan kecakapan kepemimpinan pekerja yang begitu kuat bahwa kecakapan kepemimpinan pekerja akan memberikan kontribusi pada efektivitas pelayanan seorang pekerja. Semuanya ini diharapakan akan memberi suatu gambaran dan pemahaman serta motivasi bagi para pekerja untuk melihat dan mengembangan pentingnya sebuah mentoring dalam pelayanan guna meningkatkan kecakapan kepemimpinan pekerja yang akan memberikan kontribusi berkembangnya pelayanan di Gereja Kemah Injil Indonesia Daerah Pontianak.

\section{Kepustakaan}

Anderson, Loorin W. David R. Karthohl. Kerangka Landasan Untuk Pembelajaran, Pengajaran, dan Asesmen: Revisi Taksonomi Pendidikan Bloom. Yogyakarta: Pustaka Pelajar, 2010.

Barna, George. Leadership on Leadership. Malang: Gandum Mas, 2002.

Brake, Andrew. Spritual Formation. Bandung: Kalam Hidup, 2014.

Clinton, Robert. Pembentukan Pemimpin Sejati. Jakarta: Metanoia, 2004. . Pengembangan Kepemimpinan. Bandung: Lembaga Pelayanan Rohani Para Navigator Indonesia, 1992. 
Gamayanto, Indra. "Pengembangan Mentoring Management Dalam Menghasilkan High Quality Human Resource di Tingkat Universitas Dalam Menghadapi masyarakat Ekonomi Asean (MEA) Dengan Menngunakan Konsep Kiyosaki dan Blanchard ABCD Trust Methods-HSOVA." Jurnal Manajemen 13, No 2 (November 2016): 158-178.

Ghozali, Imam. Aplikasi Analisis Multivariate Dengan Progran IBM SPSS 17. Semarang: Universitas Diponegoro, 2011.

Hermastuti, A., Agus Frianto "Pengaruh Pengembangan dan Motivasi Terhadap Kinerja Karyawan di PDAM Kota Madium.” Jurnal Ilmu Manajemen 1, Nomor 3 (Mei 2013):690-700.

Hutabarat, Herdy N. Mentoring dan Pemuridan. Bandung: Kalam Hidup, 2011.

Kusnadi, Edi. Wawancara oleh Penulis. Pontianak, April 2018.

Muir, Douglas. "Mentoring and Leader Identity Development: A Case Study." Human Resource Development Quarterly 25, no. 3 (September 2014): 349-79. https://doi.org/10.1002/hrdq.21194.

Ronda, Daniel. Leadership Wisdom. Bandung: Kalam Hidup, 2011.

Muir, Douglas. "Mentoring and Leader Identity Development: A Case Study." Human Resource Development Quarterly 25, no. 3 (September 2014): 349-79. https://doi.org/10.1002/hrdq.21194.

Prihanto, Agus. "Peran Proses Mentoring Pemimpin Kaum Muda Bagi Perkembangan Pelayanan Pemuda Di Gereja." Jurnal Jaffray 16, no. 2 (6 Oktober 2018): 197-212. https://doi.org/10.25278/jj7l.vl6i2.258.

Puls, Timothy R, Laverne L Ludden, dan James Freemyer. "Authentic Leadership and Its Relationship to Ministerial Effectiveness." Journal of Applied Christian Leadership 8, no. 1 (2014): 1-22.

Sarwono, Jonathan. Analisis Jalur untuk Riset Bisnis dengan SPSS. Yogyakarta: ANDI Offset, 2007.

Sjofjan, S., Aryanan Satrya, "Analisis Pengaruh Mentoring, Sikap Verbal Agresif Atas terhadap Kepuasan Komunikasi dan Komitmen Organisasional Karyawan Pada Perusahaan." Jakarta: Fakultas Ekonomi Universitas Indonesia, 2013. Diakses 25 Februari 2018. http://lib.ui.ac.id/naskahringkas/2016-03/S46328-

Sofyati\%20Sjofjan

Sugiyono. Metode Penelitian Pendidikan Pendekatan Kuantitatif, Kualitatif, dan R \& D. Bandung: Alfabeta, 2010.Tim Penyusun. Kamus Besar Bahasa Indonesia. Jakarta: Balai Pustaka, 2000.

Yeakley, Tom. Character Formation for Leaders. Bandung: Kalam Hidup, 2013.

Zschech, Darlene. The Art of Mentoring. Malang: Literatur SAAT, 2013. 